\title{
Environmental life cycle implications of upscaling lithium-ion battery production
}

\author{
Mudit Chordia $^{1}$ (D) Anders Nordelöf ${ }^{1} \cdot$ Linda Ager-Wick Ellingsen ${ }^{2}$
}

Received: 21 July 2021 / Accepted: 3 September 2021 / Published online: 23 September 2021

(c) The Author(s) 2021, corrected publication 2022

\begin{abstract}
Purpose Life cycle assessment (LCA) literature evaluating environmental burdens from lithium-ion battery (LIB) production facilities lacks an understanding of how environmental burdens have changed over time due to a transition to large-scale production. The purpose of this study is hence to examine the effect of upscaling LIB production using unique life cycle inventory data representative of large-scale production. A sub-goal of the study is to examine how changes in background datasets affect environmental impacts. Method We remodel an often-cited study on small-scale battery production by Ellingsen et al. (2014), representative of operations in 2010, and couple it to updated Ecoinvent background data. Additionally, we use new inventory data to model LIB cell production in a large-scale facility representative of the latest technology in LIB production. The cell manufactured in the small-scale facility is an NMC-1:1:1 (nickel-manganese-cobalt) pouch cell, whereas in the large-scale facility, the cell produced in an NMC-8:1:1 cylindrical cell. We model production in varying carbon intensity scenarios using recycled and exclusively primary materials as input options. We assess environmental pollution-related impacts using ReCiPe midpoint indicators and resource use impacts using the surplus ore method (ReCiPe) and the crustal scarcity indicator.

Results and discussion Remodelling of the small-scale factory using updated background data showed a $34 \%$ increase in greenhouse gas emissions - linked to updated cobalt sulfate production data. Upscaling production reduced emissions by nearly $45 \%$ in the reference scenario (South Korean energy mix) due to a reduced energy demand in cell production. However, the emissions reduce by a further 55\% if the energy is sourced from a low-carbon intensity source (Swedish energy mix), shifting almost all burden to upstream supply chain. Regional pollution impacts such as acidification and eutrophication show similar trends. Toxic emissions also reduce, but unlike other impacts, they were already occurring during mining and ore processing. Lastly, nickel, cobalt, and lithium use contribute considerably to resource impacts. From a long-term perspective, copper becomes important from a resource scarcity perspective.

Conclusions Upscaling LIB production shifts environmental burdens to upstream material extraction and production, irrespective of the carbon intensity of the energy source. Thus, a key message for the industry and policy makers is that further reductions in the climate impacts from LIB production are possible, only when the upstream LIB supply chain uses renewable energy source. An additional message to LCA practitioners is to examine the effect of changing background systems when evaluating maturing technologies.
\end{abstract}

Keywords Environmental life cycle assessment $\cdot$ Lithium-ion battery $\cdot$ Battery cell production $\cdot$ Upscaling $\cdot$ Electric vehicles

\section{Introduction}

Acceptance of electric vehicles (EVs) as a mode of private transport is evident from their growing stocks in the recent years (Crabtree 2019; ICCT 2020). A key enabler for an

Mudit Chordia

mudit@chalmers.se

1 Division of Environmental Systems Analysis, Chalmers University of Technology, 41296 Gothenburg, Sweden

2 Institute of Transport Economics, 0349 Oslo, Norway increase in vehicle stocks has been the production capacity expansion of lithium-ion batteries (LIBs), which is the dominant energy storage technology for EVs (Blomgren 2016; Ding et al. 2019). The average capacity of LIB production plants has grown from $0.5 \mathrm{GWh}$ in 2015 to about 7 GWh in 2020 (Benchmark Mineral Intelligence 2020). The increase in production capacity is due to commissioning of new production plants, upscaling of existing plants, maturing supply chains, and improvements in production technology (Strauch 2020). At the cell level, nickel, manganese, and cobalt (NMC)-based cathode chemistries represent a 
majority share of the EV storage capacity globally in the last decade (Tsiropoulos et al. 2018). Although the share of nickel, manganese, and cobalt in the active cathode material vary based on the application, high nickel content chemistries are currently the most likely candidates for highdensity LIBs. This is due to advantages high nickel content chemistries offer in terms of energy capacity, energy density, power capability, and cost (Manthiram 2017). However, they face technical challenges in terms of calendar storage loss, capacity loss, cycle life, and thermal stability (Ding et al. 2019). High nickel content in NMC implies a lower cobalt share per unit mass of the active cathode material. Cobalt content is relevant because globally $70 \%$ of all cobalt is produced in the Democratic Republic of Congo (USGS 2020), which is known for pervasive mining practices (Sharma and Manthiram 2020). In addition, such a high supply concentration exposes cobalt to price fluctuations (Wentker et al. 2019). Thus, there are technical, social, and economic incentives for adopting high nickel content chemistries in LIBs.

At the core of the ongoing transition in the automotive sector is a growing environmental consciousness and the need for energy security in the society (Greene et al. 2013). The life cycle assessment (LCA) methodology is commonly used to provide a holistic approach to assessing environmental impacts from the EV life cycle, which includes production, use, and end-of-life (EoL) phases (Nordelöf et al. 2014). LCA studies of EVs point to the source of electricity for charging and high energy demand during LIB production as key sources of environmental impacts (Nordelöf et al. 2014). Using renewable energy to charge the batteries can lower the environmental impacts from EVs in their use phase (Holland et al. 2016; Onat et al. 2015; Egede 2017). Additionally, supply chains with high shares of renewable energy can also lower the emissions from the upstream material production phase (Kelly et al. 2019). Aichberger and Jungmeier (2020) compiled a literature review of 50 LCA studies and found the average greenhouse gas emissions for LIB production to be approximately $120 \mathrm{~kg} \mathrm{CO}_{2}$-eq. $/ \mathrm{kWh}$. However, Ellingsen et al. (2017) have shown that there is a wide range for these results; from 38 to $356 \mathrm{~kg} \mathrm{CO}_{2}$-eq./ $\mathrm{kWh}$. This variation in assessment results can be explained by diverging technical scopes, and lack of representative data for key parameters such as battery lifetime, energy density, and energy demand in cell production in the LCA studies (Peters et al. 2017; Peters and Weil 2018). Specific to the energy demand, small or underutilized facilities could lead to an overestimation of environmental impacts from cell manufacturing (Aichberger and Jungmeier 2020). Similarly, high energy demand of throughput independent equipment (such as dry rooms) can result in high energy intensity in low throughput facilities (Dunn et al. 2015a). Production methods and location also play a part in determining the energy demand (Ellingsen et al. 2015). Peters et al. (2017) conducted a review of LCA literature on LIBs comparing the key technical parameters used in the studies with industry data to understand the relevance of modelling choices on study results. Of the 79 studies identified, less than half provided sufficient data for extracting information about environmental impacts, and only 7 relied exclusively on their own life cycle inventory (LCI) data for the processes investigated.(Peters et al. 2017) This highlights the interdependency of studies in terms of LCI data and thus the lack of representative data for different technical scopes in the LCA studies.

Several studies published in the LCA literature on LIBs present results based on the publicly available model called GREET (Greenhouse gases, Regulated Emissions, and Energy use in Transportation). The GREET model provides inventory data for the entire life cycle of a vehicle and is supplemented by the "BatPac" model (Nelson et al. 2019), which provides data for different cell types and chemistries. Ease of availability and periodic inventory updates (Wang et al. 2018; Dai et al. 2017, 2018b) makes GREET a convenient source of data for investigating novel battery components. However, this implies that several LCA studies using the GREET model (Dai et al. 2019; Yuan et al. 2017; Wang et al. 2019; Deng et al. 2018; Kelly et al. 2019; Raugei and Winfield 2019) represent the same production facilities (and technical scopes) and rely on similar methodological assumptions. Another commonly used data source is the Ecoinvent database (Weidema et al. 2013; Wernet et al. 2016), which provides datasets for modelling background processes for a wide variety of technologies and processes, including, but not specific to LIB production. However, current Ecoinvent datasets for LIB production are not representative of upcoming cathode chemistries and novel production developments. As a response, a recent article by Crenna et al. (2021) describes proposed updates to Ecoinvent, but these are in fact based extensively on the GREET model.

Apart from limited sources of primary data covering key aspects of LIB production and the high interdependency in the studies in terms of LCI data, the LCA literature on LIB production is narrow in its coverage of large-scale production facilities - i.e., facilities typically producing LIBs at gigawatt scale (giga-scale) annually. Consider for instance the often-cited Ellingsen et al. (2014) - conducted by one of the authors of the present work - analyses LIB production at megawatt scale. Amongst the studies assessing largescale (gigawatt) LIB production, Dai et al. (2019) and Kim et al. (2016) analyzed facilities with $2 \mathrm{GWh}$ and 3-4 GWh production capacity, respectively, although it is likely that the facility modelled by Kim et al. (2016) was operating at lower than its designed capacity (Dai et al. 2019). Thus, considering the growing investments in LIB production (Lutsey et al. 2018), there is a need to investigate the life 
cycle implications of upscaling LIB production, especially for high nickel content chemistries. Lastly, there is a need to supplement existing LCA literature with additional original data sources for cell production that are representative of giga-scale LIB production.

\subsection{Purpose}

The purpose of the study is to examine the effect of upscaling LIB cell production from an environmental life cycle perspective. To accomplish this, we model and compare production in a small-scale and a giga-scale factory. The small-scale factory is modelled based on the work previously published by Ellingsen et al. (2014), and the giga-factory is modelled using data compiled from three environmental permit applications and the energy report of a giga-scale battery cell manufacturing facility in Sweden (Northvolt 2020, 2019, 2018, 2017). By providing new inventory data representing the high-end for material and energy use values, but with a potential for reductions, the analysis indicates a bottom reference level for environmental impacts of largescale LIB cell production.

We adopt the original small-scale factory, which was modelled by Ellingsen et al. (2014) using Ecoinvent v2.2 background datasets, to the latest Ecoinvent v3.7.1 database for comparability with the giga-factory. Updates to background datasets represent better data availability and progress in the real-world industrial activities. Thus, another sub-goal of the study is to understand how changes in background datasets affect environmental impacts. The foremost intended audience of this study are LIB production industry and policy makers driving action towards decreasing environmental burdens from battery production. The study also aims to inform LCA practitioners modelling and analyzing LIBs.

\section{Methods}

\subsection{Life cycle scope and the functional unit}

The small-scale factory is modelled using inventory data published by Ellingsen et al. (2014). The study was first replicated using Ecoinvent v2.2, i.e., the same version used in original study, and analysed by comparing it with the original study results for global warming impacts at the cell level. The model was judged acceptable as the deviation in result was less than $0.2 \%$ in this comparison, likely caused by truncation errors. This model was then coupled with Ecoinvent v3.7.1 with some adjustments in the model relating to updates in the Ecoinvent database. These adjustments are described in Sect. S4 of the Supporting information (SI). Hereafter, we refer to the replicated model of the small-scale factory as "Small-2.2" and the remodelled version of the small-scale factory as the "Small-3.7" model. The largescale factory (the "Giga-3.7" model) is modelled using data compiled from the environmental permit applications of a giga-scale battery cell manufacturing facility in Sweden (Northvolt 2019, 2018, 2017). This implies that energy demand, input material requirements, and emissions are conservative estimates to which future real-world activities must comply, i.e., an upper-cap limit. The data collection for the giga-factory is described in the Sect. S1 of the SI. Table 1 summarizes the LCA models analysed in this study.

As the goal of the study is to examine the impacts of LIB cell production at the different scales, the life cycle scope is from cradle to the cell factory gate. The study includes extraction and production of raw materials, cell, and cell sub-component production, as well as energy generation and transmission to the factory. Figure 1 shows the system boundaries of the LCA model for the giga-factory modelled in this study. The foreground system represents a production facility that sources raw materials, process chemicals, additives, water, and energy (electricity, heat, and cooling) for LIB cell production. The typical outflows from the facility include the losses from cell production such as hazardous and non-hazardous waste, recyclable production scrap, emissions to air and water, and water returned to source after treatment. The background system represents all upstream activities of the life cycle and is modelled using the Ecoinvent v3.7.1 cut-off system model (Wernet et al. 2016). In this version of the database, burdens for handling recyclable materials and wastes generated in the cell production are assigned to the main product, leaving by-products free of burden after the cut-off point (Steubing et al. 2016).

An intermediate system was added to account for the services needed to convert materials from their intermediate state (as provided by the background system) to an adequate precursor form that matches the specific input required by the foreground system. These intermediate system processes are not covered in the data collection for the activities inside the giga-factory. The processes covered in the intermediate system include (i) the production of pre-fabricated cell components (cobalt sulfate solution used in the active cathode

Table 1 Summary of LCA models analysed in the study

\begin{tabular}{llll}
\hline LCA model & Cell type & $\begin{array}{l}\text { Ecoinvent } \\
\text { version }\end{array}$ & Description \\
\hline Small-2.2 & $\begin{array}{l}\text { Pouch } \\
\text { NMC 111 }\end{array}$ & 2.2 & $\begin{array}{c}\text { Replication of Ellingsen } \\
\text { et al. (2014) with }<0.2 \% \\
\text { error }\end{array}$ \\
Small-3.7 & & 3.7 .1 & $\begin{array}{l}\text { Small-2.2 remodeled with } \\
\text { Ecoinvent v3.7.1 }\end{array}$ \\
Giga-3.7 & $\begin{array}{l}\text { Cylindrical } \\
\text { NMC 811 }\end{array}$ & 3.7 .1 & Production in giga-factory \\
\hline
\end{tabular}




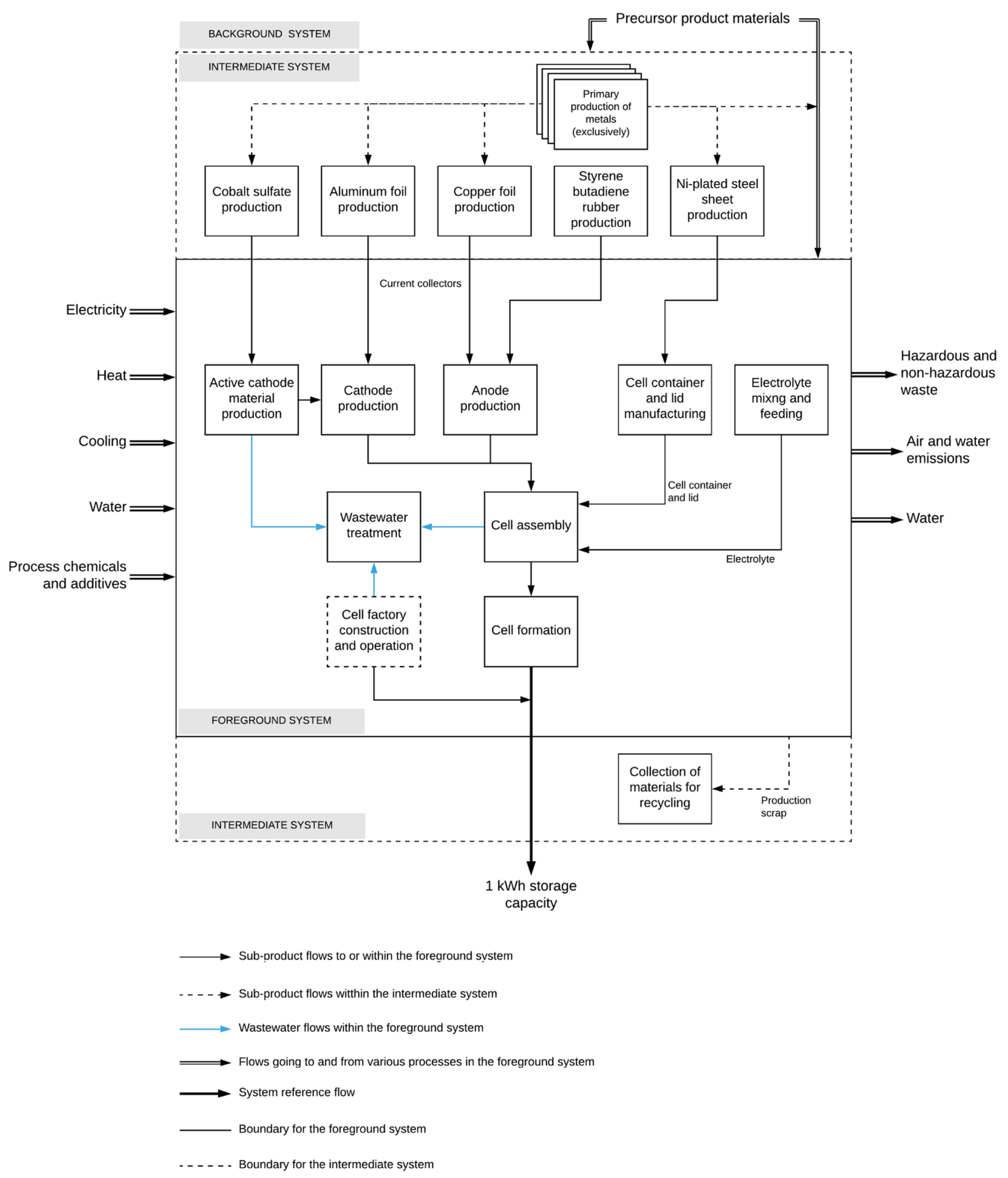

Fig. 1 Boundaries defined between the background, intermediate and foreground systems for the Giga-3.7 model of large-scale LIB production. Note: The "Cell factory construction and operation" unit process is a factory wide support process, and the schematic shows how the unit process is linked into the model 
material), aluminium and copper foils used as current collectors, styrene butadiene rubber used as a binder in anodes, and nickel-plated steel sheet used as the cell container body and lid); (ii) production pathways for metals or metal salts (aluminium, copper, steel, nickel sulfate, and lithium salts) which represent primary extraction only without any mixing with recycled materials; (iii) energy inputs for district heat and for cooling in Sweden; and (iv) transportation processes for the collection of production scrap and delivery to the scrap sorting and treatment facility. All processes within the intermediate system boundary are explained in detail in Sect. S5 of the SI. This study represents production processes in a steady-state system. Thus, we use an attributional type of LCA to calculate the relevant physical inflows and outflows associated with the cradle-to-gate life cycle of LIB production (Baumann and Tillman 2004). As the function of a battery cell factory is to produce cells that store and supply energy, the functional unit chosen is $1 \mathrm{kWh}$ of battery cell storage capacity.

\subsection{Supply scenarios and impact assessment indicators}

We analyze LIB production in the small and giga-scale factories in two energy supply scenarios of varying carbon intensity. We also investigate two options for the material input, either including recycled content or consisting of exclusively primary metals. In the context of this study, varying carbon intensity scenarios for energy inputs are modelled as the South Korean and the Swedish energy mix. South Korea is home to a number of LIB manufacturers, produces a large share of LIBs globally (Lutsey et al. 2018), and has been used as reference case in a number of LCA studies on LIB production (Ellingsen et al. 2014; Philippot et al. 2019; Kim et al. 2016). Further, fossil fuels contribute to almost $70 \%$ of the electricity supply mix in South Korea, which makes it a relevant case for comparison with grids with low-carbon intensity. Hence, the South Korean energy mix is chosen as the representative case of LIB cell production in the "reference scenario" (approximately $690 \mathrm{~g} \mathrm{CO}_{2}$-eq./kWh of supplied electricity). The Swedish energy mix consists of a large share of renewables (e.g., hydropower, wind, and bioenergy) and nuclear power and is thus chosen as the representative case for "low-carbon scenario" (approximately $40 \mathrm{~g} \mathrm{CO}_{2}$-eq./kWh). It is worth highlighting that the emissions in the real-world related to electricity generation could vary as compared to values calculated from different LCA databases, including Ecoinvent. This is due to the differences in technical system boundaries chosen and representative energy generation technologies used to model the real-world technologies. The modelling of input metals or metal compounds with recycled content were based on existing market data for aluminium, copper, steel, nickel, and lithium in Ecoinvent. While lithium carbonate and nickel contain very little recycled input $(0.1 \%$ and $0.2 \%$, respectively), traded grades of aluminium, steel, and copper relevant for battery cells incorporate significant amounts (roughly 30\%, 20\%, and $20 \%$, respectively). However, due to a relatively nascent market for the second-use battery materials and that some of these recycled materials may not meet the high purity requirements for cell components (Pinegar and Smith 2019). Thus, most of the analysis is focused on the material inputs deriving from exclusively primary sources. Full details on how this option for the material input was modelled are provided in Sect. S5 of the SI.

Next, the impact assessment is carried out using the ReCiPe midpoint method with a Hierarchist perspective (Huijbregts et al. 2017). Refer to the Sect. S6 of the SI for more details on impact indicator types and descriptions. Specific attention is given to global warming, acidification, and human toxicity in the main article. Complete impact category results are reported in Sect. S6 of SI. Resource use, an area of attention for sustainability of LIBs, is analyzed using two different LCIA methods for mineral resource scarcity: the surplus ore method included in $\mathrm{ReCiPe}$ and the crustal scarcity indicator (Arvidsson et al. 2020a, b).

\subsection{Technical and temporal scope}

The LIB cell produced in the present day giga-factory is a cylindrical cell of 21,700-type, intended for automotive applications. This cell type has an outer diameter of $21 \mathrm{~mm}$, is $70 \mathrm{~mm}$ in length, and weighs between 67 to $69 \mathrm{~g}$ (Quinn et al. 2018). The cell chemistry analyzed is NMC-8:1:1 where the ratio $8-1-1$ is an indicator of the active cathode material composition, i.e., $80 \%$ nickel, $10 \%$ manganese, and $10 \%$ cobalt. The model is valid for cells within the energy density range of $210-240 \mathrm{Wh} / \mathrm{kg}$. The active anode material is made of synthetic graphite. The positive and negative current collectors are made of aluminium and copper foils, respectively. The electrolyte is a mixture of lithium hexafluorophosphate $\left(\mathrm{LiPF}_{6}\right)$, ethylene carbonate (EC), ethyl methyl carbonate (EMC), dimethyl carbonate (DMC), and small quantities of additives such as vinyl carbonate (VC) and fluoroethylene carbonate (FEC). The entire cell assembly is housed in a cylindrical container made of nickel-plated steel. The mass and chemical compositions of the active cathode material are the key determinants of the cell's storage capacity and power, respectively (Smekens et al. 2016). With the industry efforts to reduce the cobalt content of LIB, it is likely that NMC-8:1:1 will become an increasingly popular choice in the future (Tsiropoulos et al. 2018; Olivetti et al. 2017; Li et al. 2020), especially for automotive applications. 
Details of the cell mass composition and the energy demand in cell production are provided in Table S2-1 and Table S2-3 of the SI. The LIB cell production in the small-scale factory corresponds to a factory setup roughly around 2010, making pouch cells for automotive applications. The cell chemistry analyzed here is NMC-1:1:1. We refer readers to the Sect. 2 section of the Ellingsen et al. (2014) study for comprehensive description of the cell production and modelling procedure. The energy density of the NMC-111 pouch cell is approximately $170-180 \mathrm{Wh} / \mathrm{kg}$. Comparing a nickel rich cathode such as the NMC-8:1:1 housed in a cylindrical cell to an NMC-1:1:1 pouch cell is a methodological approach adopted to reflect the progress of the LIB technology. This includes evolving trends in cell geometry and the development of high-density nickel-rich chemistries in recent years (Gourley et al. 2020; Li et al. 2020).

\section{Results and discussion}

\subsection{Energy demand}

The small-scale factory is representative of approximately $70 \mathrm{MWh}$ annual cell production capacity. It sources only electricity as energy input due to the process design of the factory. The electricity demand for the factory was determined based on data measured over an 18-month period and varies significantly (590-2300 MJ/kWh) with the production output. The lower bound value is used for comparison with the giga-factory as it represents full capacity production. The giga-factory represents about $16 \mathrm{GWh}$ annual cell production capacity and uses a combination of heat, cooling, and electricity for cell production. The energy demand in the giga-factory is determined based on process simulations and represents a conservative estimate, which is expected to decrease once the factory is operational and energy efficiency measures are installed (Northvolt 2020). The total electricity requirement in the giga-factory is $58 \%$ lower, i.e., $245 \mathrm{MJ} / \mathrm{kWh}$, compared to the small-scale factory. The giga-factory also requires about $27 \mathrm{MJ} / \mathrm{kWh}$ of heat and $108 \mathrm{MJ} / \mathrm{kWh}$ of cooling which vary depending on the climatic conditions surrounding the factory. For example, the humidity, air temperature, and presence of a river or a stream can determine the amount of heat and cooling that can be substituted with naturally available means. Overall, the transition to large-scale production indicates higher energy efficiency and material utilization. It is also likely that, with time, production processes for specific cell production steps have matured and contributed to this overall development. However, since detailed information about the production processes was not available in the small-scale factory, as it has been for the giga-factory, improvements in specific cell production processes were not explored further.

\subsubsection{Electricity demand}

In the giga-factory, the electricity demand is highest during the cell formation process, approximately $53 \mathrm{MJ} / \mathrm{kWh}$. Cell formation refers to the electrochemical reactions between the electrolyte and the active anode material that results in the formation of a passive interfacial layer on the active anode material (Wood et al. 2015). This interfacial layer is formed during the initial charge-discharge cycles and prevents further reactions of the anode material (Arora et al. 1998). Charge-discharge cycles are followed by capacity grading after which the cells typically have around $70 \%$ charge left in them when leaving the factory gate. In general, LCA literature on LIB production varies in their scope when defining the cell formation step. For example, Dai et al. (2019) and Sun et al. (2020) state that $4 \mathrm{MJ} / \mathrm{kWh}$ and $11 \mathrm{MJ} / \mathrm{kWh}$, respectively, are required for charging the cells, while Yuan et al. (2017) state pre-charging to require about $2 \mathrm{MJ} / \mathrm{kWh}$. Dai et al. (2019) calculate electricity requirements for cell formation based on the energy required to charge the cell once with $90 \%$ efficiency and state that the electricity from the discharge cycle in cell formation is utilized. Per our correspondence with battery experts from the industry, it is estimated that up to $30 \%$ losses could occur over the charging and discharging cycles alone. Nevertheless, an implication of using conservative data from environmental permit applications is that efficiency measures such as utilizing the discharge cycle (of a set of batteries) to charge another set are not considered.

The second highest share of electricity demand comes from overall factory operations and utilities, i.e., approximately $18 \%$ - of which $26 \mathrm{MJ} / \mathrm{kWh}$ is used by the dry room. Dry rooms are throughput independent and sized according to maximum factory capacity. This electricity requirement for the dry room in this study is in accordance with other published values in literature for large-scale LIB production (Dai et al. 2019; Sun et al. 2020).

In the giga-factory model, we calculate the electricity required for intermediate steps when the cathode and the anode are produced as complete subparts, including (slurry) mixing, coating, drying, cutting, calendering, slitting, and solvent recovery. Electricity required for these steps during cathode and anode assembly together account for $83 \mathrm{MJ} / \mathrm{kWh}$. Prior to the cathode assembly, our model defines active cathode material production as a separate activity where precursor materials are blended, which requires approximately $38 \mathrm{MJ} / \mathrm{kWh}$. Additionally, the electricity used for other steps in cell production, such as electrolyte mixing and feeding, cell container production, cell assembly and wastewater treatment, collectively account for about $28 \mathrm{MJ} / \mathrm{kWh}$. Electricity demand for electrode production is indirectly linked to the cell chemistry and the use of solvents in active material slurry preparation 
for the electrodes. Typically, cell producers use N-methyl2-pyrrolidone (NMP) as a solvent in the mixture which requires stringent handling due to its volatility. Use of aqueous slurries (as in the anode preparation process in the giga-factory model) or applying of dry powder on the current collectors using pulsed laser or sputtering deposition are options for reducing electricity use (Ludwig et al. 2016). Hence, in addition to being environmentally benign (Zackrisson et al. 2010), using water as a solvent could potentially lower energy demand in slurry preparation for LIB electrodes (Wood et al. 2018).

High demand for electricity as reported for the gigafactory is a consequence of using permit applications. Such permits typically provide conservative estimates based on process simulation and represent an upper cap in terms of energy and material demand as well as emissions. Implementing energy efficiency measures such as recovering heat losses from compressors, recirculating air in dry rooms and recirculating heat in the electrode coating steps could provide significant savings in an operational factory (Northvolt 2020). For example, as much as $40 \%$ of the formation electricity can potentially be saved through process optimization (Northvolt 2020). Even so, there is still discrepancy with other studies of giga-factories. For example, Dai et al. (2019) model a total electricity use of $30 \mathrm{MJ} / \mathrm{kWh}$, of which $4 \mathrm{MJ} / \mathrm{kWh}$ is used for charging and all remaining for operating dehumidifiers and chillers. Remaining equipment and processes are assumed to use negligible amounts of electricity. Sun et al. (2020) report a total electricity demand of about $68 \mathrm{MJ} / \mathrm{kWh}$ for cell production, of which about $30 \mathrm{MJ} / \mathrm{kWh}$ are used for electrode processing and $11 \mathrm{MJ} / \mathrm{kWh}$ for formation. Important factors explaining why Dai et al. (2019) and Sun et al. (2020) report lower electricity consumption is that active cathode material powder production is outside their factory scope, and that their data represent sites which have been optimized for cost efficient operation. There is also a difference in how the factories generate steam: by means of electricity as in the Giga-3.7 model (Northvolt 2020 ) or by means of heat, as discussed in the following section. Both Dai et al. (2019) and Sun et al. (2020) refer only to core processes and point to high electricity consuming equipment such as dry and clean rooms but not to the broad set of activities that make up complete cell production lines or to other factory wide operations, utilities, and support processes. This underreporting due to data gaps partially explains the lower energy demand in these studies.

\subsubsection{Heat demand}

The total heat demand in the giga-factory is about $27 \mathrm{MJ} /$ $\mathrm{kWh}$. This is mainly due to dry rooms, which in addition to their electricity use account for over $90 \%$ of the total heat demand (Northvolt 2020). This includes maintaining an atmosphere with moisture content lower than $100 \mathrm{ppm}$ in the operational areas (Ahmed et al. 2016). This is the reason cell production processes such as cell assembly and formation cycling are carried out in "dry rooms" (Dunn et al. 2015a).

The overall energy demand for heat processes is also influenced by the selection of energy carriers and heat sources, i.e., if steam or hot water is brought in from external facilities, or if electricity or natural gas burning is used for on-site generation. In the studied giga-factory, a combination of district heat and electrically generated steam is used to meet the heat demand. Several LCA studies on LIB production model heat demand through a combination of electricity, steam, and natural gas combustion (Dai et al. 2019; Dunn et al. 2015b; Sun et al. 2020; Wang et al. 2019; Deng et al. 2018; Yuan et al. 2017). Both Sun et al. (2020) and Dai et al. (2019) point to dehumidification and drying in terms of heat use, with the former stating a $34-\mathrm{MJ} / \mathrm{kWh}$ steam requirement and latter $170 \mathrm{MJ} / \mathrm{kWh}$, respectively, based on the GREET model (Dai et al. 2017). Note that in the small-scale factory model, the heating requirements were met through electricity exclusively (Ellingsen et al. 2014).

\subsubsection{Cooling demand}

The cooling demand in the giga-factory is due to multiple production processes but again electrode production and factory wide operations that include the dry room are the key processes, accounting for about $25 \%$ of the cooling energy demand. The cooling demand during electrode production is for condensing and recycling of the solvents and binders, specifically during the coating step. A smaller share of cooling energy (10\%) is also required for wastewater treatment. In the model, we assume cooling requirements are met through adsorption chillers operating on heat, being the most common cooling generation method in Sweden (Lejestrand 2020). Sun et al. (2020) do not specify any cooling requirements, while Dai et al. (2019) state that electricity is utilized for meeting cooling needs. The small-scale factory does not specify any cooling requirements.

\subsection{Environmental impacts}

\subsubsection{Replication of the Ellingsen et al. (2014) study}

The LCA study of a small-scale factory by Ellingsen et al. (2014) was replicated and analyzed using both Ecoinvent v2.2 and v3.7.1 data (Fig. 2: Small-2.2 and Small-3.7, respectively). This modification of the background system resulted in an increase of the global warming impacts from about 140 to $185 \mathrm{~kg} \mathrm{CO}_{2}$-eq./ $/ \mathrm{kWh}$. Changes to the cobalt sulfate production data accounted for more than half of the 


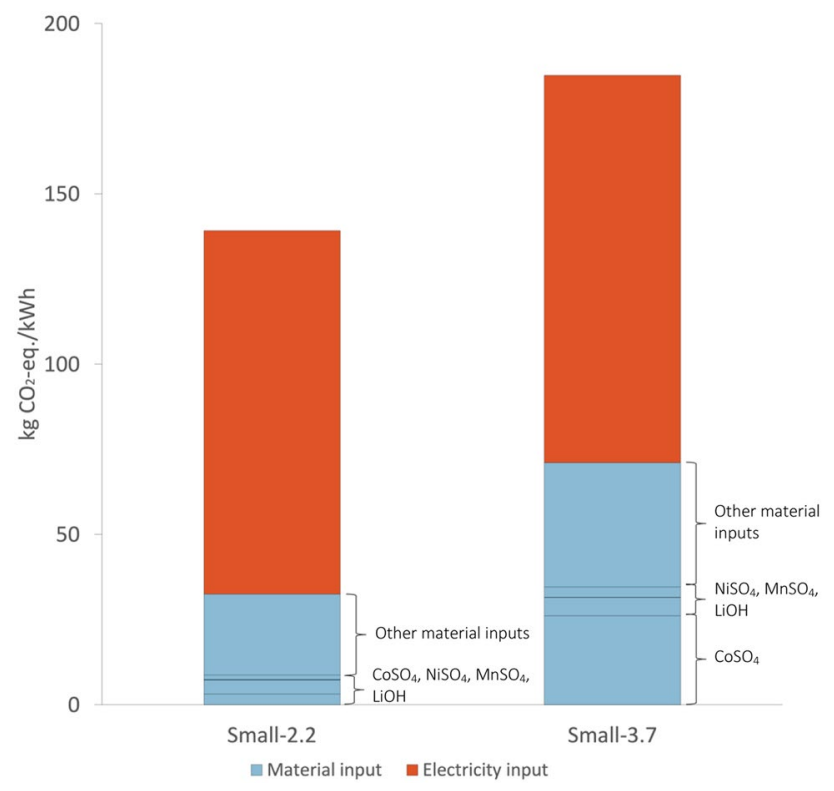

Fig. 2 Comparison of global warming impacts for the small-scale factory modelled using different Ecoinvent versions (with recycled content), i.e., version 2.2 originally used by Ellingsen et al. (2014), and the latest version available at the time of the study

increase in impacts, followed by copper foil production and electricity generation in the reference scenario (South Korean electricity mix).

The cobalt sulfate production data used in the original study by Ellingsen et al. (2014) was based on inventory data published by Majeau-Bettez et al. (2011) who, in turn, had modelled cobalt sulfate production by adjusting the inventories for primary cobalt metal in Ecoinvent v2.2 with stoichiometric calculations for the sulfate solution. Looking further back, the Ecoinvent v2.2 database relied on production routes aggregated according to their market share in 1994. In the Small-3.7 (and Giga-3.7) model, we model the production of cobalt sulfate with new primary data from a refinery in Canada (Ausenco 2020), with cobalt hydroxide as input. The cobalt hydroxide production data, taken from Ecoinvent v3.7.1, represents an industry average covering $30 \%$ of the world production of refined cobalt in 2012 (CDI 2016). Changes in other background datasets like copper foil production and the South Korean electricity mix also resulted in increased impacts in the Small-3.7 model. These were due to a change in shares of primary metal input in copper foil and shifts in the mix of energy sources for electricity generation, respectively, as well as changes in the data representing these processes. The replication and analysis of the Ellingsen et al. (2014) study using different versions of the Ecoinvent background databases show that improvements in data quality (such as the case for cobalt hydroxide production) and changes in technical representation (such as the share of primary and recycled content or share of electricity mix) affect the overall results considerably and hence the implications of the study. Of course, unforeseen gaps can per definition not be avoided, but the replication results point to the importance of revisiting earlier results and conclusions in cases when old or proxy data of uncertain quality was the best available modelling choice. The results of the Small3.7 model, albeit higher than for the Small-2.2 model, thus become a more accurate baseline for comparison with the Giga-3.7 model to understand the implications of upscaling LIB production.

\subsubsection{Global warming}

The global warming impacts of small-scale and giga-scale LIB production are shown in Fig. 3. The Small-3.7 model coupled to the reference scenario and exclusively primary metals results in $188 \mathrm{~kg} \mathrm{CO}_{2}$-eq. $/ \mathrm{kWh}$ of total greenhouse gas (GHG) emissions, which reduce to $109 \mathrm{~kg} \mathrm{CO}_{2}$-eq./kWh for the Giga-3.7 model. Further, when the Giga-3.7 model is coupled to the low-carbon scenario, the impacts reduce to $50 \mathrm{~kg} \mathrm{CO}$-eq./kWh. The choice of using primary metals over recycled content has a relatively minor influence on global warming impacts in this study. Further, it is also likely that due to the high purity requirements of materials used in batteries, recycled metals may not meet the functional needs of some components (Pinegar and Smith 2019), thus making the results with only primary inputs more relevant.

Focusing specifically on the gate-to-gate (factory) impacts, the reduction in emissions from upscaling irrespective of the source of energy supply is due to improved energy and material efficiency. The higher energy efficiency is reflected in lower emissions from the electricity, heat, and cooling use in the giga-factory. For example, the emissions from electricity supply in the Small-3.7 model reduce from 113 to $47 \mathrm{~kg} \mathrm{CO}_{2}$-eq. $/ \mathrm{kWh}$ for the Giga-3.7 model, when coupled to the reference scenario. The gigafactory also requires heat and cooling, which adds about $17 \mathrm{~kg} \mathrm{CO}_{2}$-eq. $/ \mathrm{kWh}$ emissions for the reference scenario. The total impact from electricity, heat and cooling usage in Giga-3.7 model, assuming the low-carbon scenario, is about $5 \mathrm{~kg} \mathrm{CO}$-eq. $/ \mathrm{kWh}$. This exemplifies the importance of both utilizing renewable energy and the efficiency gains from upscaling. The emissions from the upstream material production phase in the Small-3.7 and Giga-3.7 model are about 75 and $45 \mathrm{~kg} \mathrm{CO}$-eq./kWh, respectively.

Apart from higher material efficiency in the giga-factory, the impacts from upstream material production are also affected by the different cell types and NMC chemistries being produced in the two factories. The giga-factory produces NMC-8:1:1 cylindrical cell, while the small-scale factory produces NMC-1:1:1 pouch cell. The NMC-1:1:1 pouch cell modelled requires approximately $2.2 \mathrm{~kg}$ active cathode material to produce $1 \mathrm{kWh}$ cell storage capacity, compared 
Fig. 3 Global warming impacts for the two factory models in the different carbon intensity scenarios
Reference scenario

Low carbon scenario

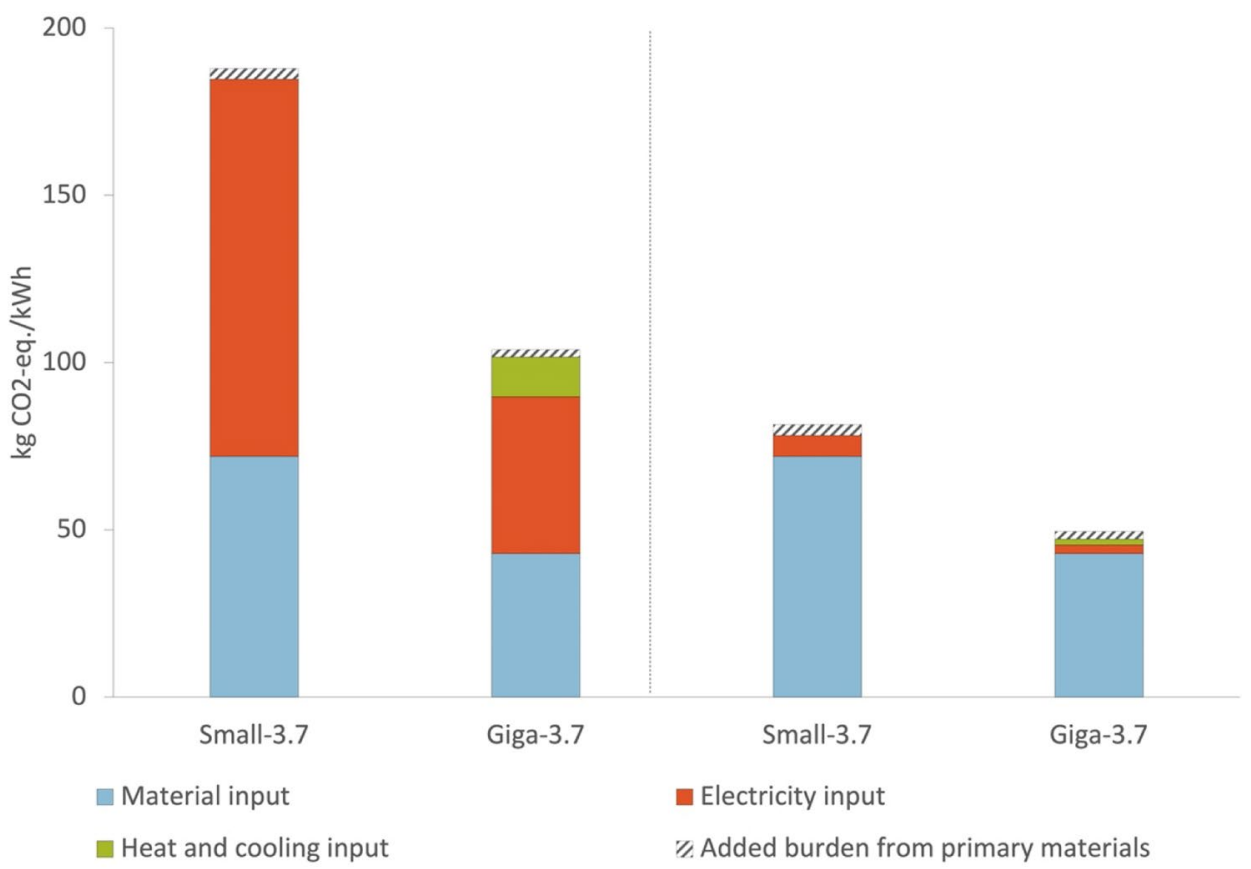

to $1.68 \mathrm{~kg}$ in the NMC-8:1:1 cylindrical cell. Noteworthy, even though the production impacts per unit mass of cobalt sulfate are five times that of nickel sulfate, the impacts from nickel sulfate are higher in the giga-factory. This is due to a reduced demand for cobalt sulfate in the NMC-8:1:1 chemistry compared to NMC-1:1:1. The shift in share of production emissions to nickel sulfate from cobalt sulfate is an important observation from this study, as it is indicative of what can be expected from the ongoing transition towards nickelrich chemistries (Ball et al. 2020; Li et al. 2020). The analysis of contributions to impacts at the unit process level in the Giga-3.7 model shows that the active cathode material production step has the highest emissions, irrespective of the source of energy. For this unit process, the contributions from the energy used in factory for the low-carbon and reference scenarios are $22 \%$ and $45 \%$, respectively. In the reference scenario, the cathode and anode production, cell formation, and factory construction and operation are the subsequent processes when ranking them according to their contributing to the total emissions. The impacts linked to these unit processes are also largely dependent on the electricity source and reduce considerably when the production is carried out in the low-carbon scenario.

Other studies on large-scale production, such as by Philippot et al. (2019), estimated $87 \mathrm{~kg} \mathrm{CO}_{2}$-eq./kWh for NCA 18,650 cylindrical cells and Kim et al. (2016) estimated about $89 \mathrm{~kg} \mathrm{CO}_{2}$-eq./kWh for LMO-NMC pouch cells, both assuming production in the South Korean electricity mix (to be compared with $102 \mathrm{~kg} \mathrm{CO}_{2}$-eq./kWh in this study when accounting for recycled content). Philippot et al. (2019) also analyzed the impact of manufacturing in different countries and estimated approximately $60 \mathrm{~kg} \mathrm{CO}$-eq./kWh for cells produced in low-carbon scenario like the Swedish electricity mix $\left(47 \mathrm{~kg} \mathrm{CO}_{2}\right.$-eq./kWh in this study, with recycled content). Sun et al. (2020) and Dai et al. (2019) investigated large-scale production with NMC chemistries and calculate 120 and $72 \mathrm{~kg} \mathrm{CO}_{2}$-eq./ $\mathrm{kWh}$, respectively, for cells produced in China. One main differentiator between the aforementioned studies compared to ours is the source of data for the active cathode material powder and its precursor materials. Kim et al. (2016), Sun et al. (2020), and Dai et al. (2019) rely on GREET, whereas Philippot et al. (2019) utilize the older inventory provided by Majeau-Bettez et al. (2011). The GREET develops LCI for nickel sulfate based on the stoichiometric calculations (Dai and Winjobi 2019; Dai et al. 2019), and for cobalt sulfate based on a single plant data operating in China (Dai et al. 2018a). In the data presented by Majeau-Bettez et al. (2011), the same metal salts are derived from stoichiometric calculations and linked to various pure metal production routes aggregated according to their market share in 1994. The data used in our study is representative of more recently available data on production pathways for precursor materials. 


\subsubsection{Other environmental impacts co-varying with global warming}

A few environmental impacts such as ground level ozone formation, particulate matter formation, stratospheric ozone depletion, and ionizing radiation co-vary with the global warming emissions - i.e., they show reductions due to upscaling. The common denominator amongst these impacts is lower electricity input per produced unit of storage capacity. Depending on the source of electricity generation, lowering fossil fuel combustion to generate electricity reduces emissions of nitrogen oxides, ammonia, and volatile organic compounds that cause hazardous ground level ozone and particulate matter, as well as chlorofluorocarbons that deplete ozone at high altitudes. Less electricity use also decreases ionizing radiation, for example caused by Radon-222, as the need for nuclear energy generation reduces. For ionizing radiation, this effect is most clearly visible for the Swedish electricity mix as it contains a high share of nuclear energy. Complete results for ozone formation, particulate matter formation, stratospheric ozone depletion, and ionizing radiation are reported in the SI.

\subsubsection{Acidification and eutrophication}

Acidification impacts for the small-scale and giga-factory are shown in Fig. 4. The acidification-related emissions in the Small-3.7 and Giga-3.7 model, coupled to the reference scenario and primary metals, are about 0.9 and $0.6 \mathrm{~kg}$ $\mathrm{SO}_{2}$-eq./kWh, respectively. However, if the production is coupled to the low-carbon scenario, the impacts reduce to 0.65 and $0.5 \mathrm{~kg} \mathrm{SO}_{2}$-eq. $/ \mathrm{kWh}$, respectively. The acidification impacts are mainly due to upstream material production. However, using a low-carbon source still reduces the acidification emissions significantly for both factory models. In contrast, the choice of recycled content over primary metals has a relatively low bearing on the overall acidification results.

The most significant contributors to acidification impacts are linked to the active cathode material and the copper foil (used as current collector). The impacts from active cathode material production are mainly linked to the nickel sulfate supply chain. Nickel sulfate is produced from class I nickel (i.e., > 99\% Ni), which in turn could be produced from both laterite and sulfidic ores (Gediga et al. 2015). Amongst the nickel production processes from sulfidic ore, smelting in various types of furnaces is the primary cause of sulfur dioxide emissions, which leads to acidification. Sulfur dioxide is formed due to oxidation of sulfur in the nickel concentrate (Moats and Davenport 2014; Crundwell et al. 2011). It is common to trap sulfur dioxide during the smelting process for the production of sulfuric acid as a way to reduce these acidification impacts (Moats and Davenport 2014). The second highest contributor to acidification impacts in both models is the production of copper foils. Copper can be produced using pyrometallurgical or hydrometallurgical processes. The
Fig. 4 Acidification impacts for the two factory models in the different carbon intensity scenarios

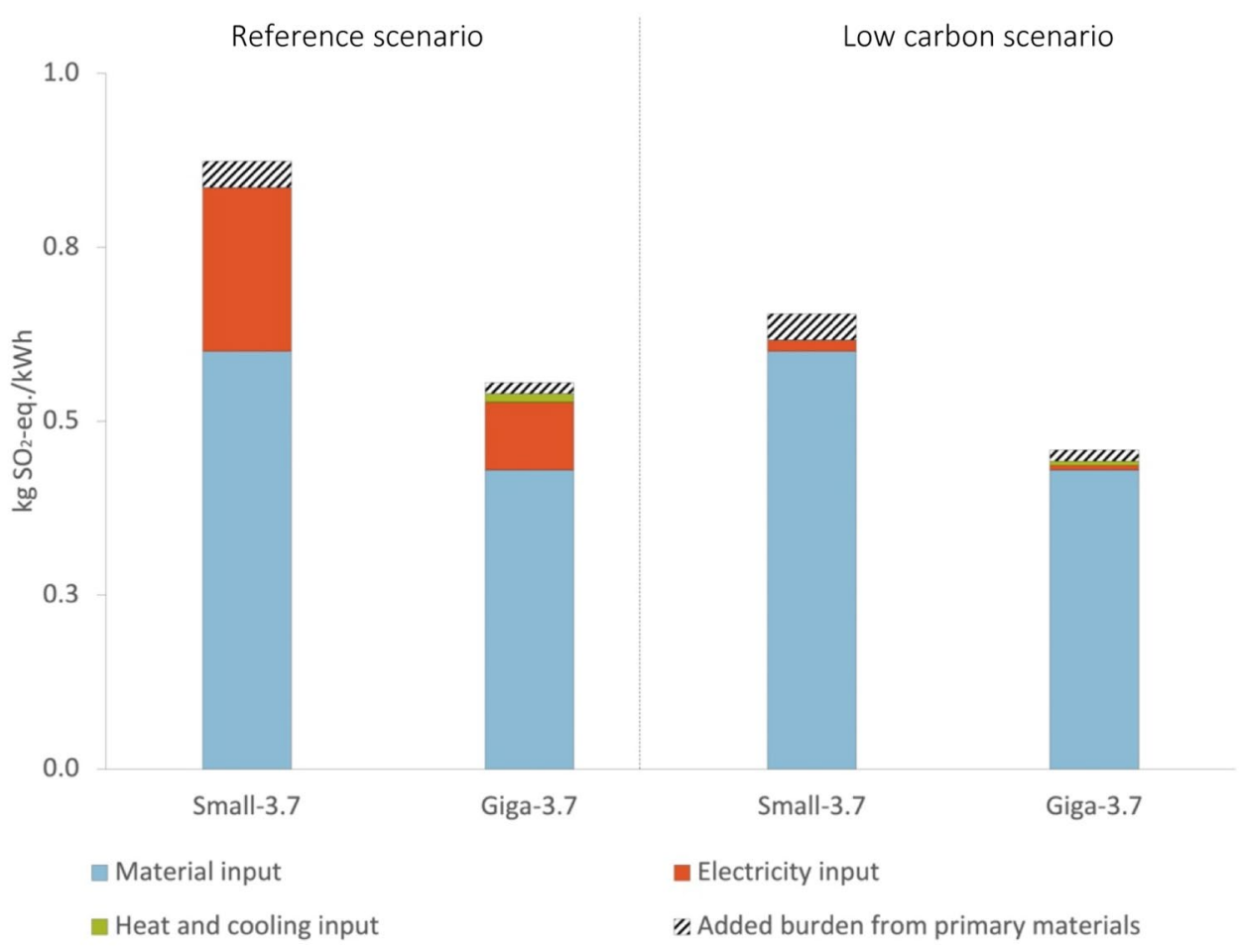


pyrometallurgical process, which is the dominant form of copper production in the world, involves producing a copper concentrate from milling followed by smelting and refining processes (European Copper Institute 2012). Like nickel smelting, smelting of copper leads to sulfur dioxide emissions (Memary et al. 2012; Fthenakis et al. 2009).

Sun et al. (2020) report $0.5 \mathrm{~kg} \mathrm{SO}_{2}$-eq. $/ \mathrm{kWh}$ for largescale LIB production. Other LCA studies analyzing largescale production report inventory results for acidifying emissions only, i.e., in terms of $\mathrm{SO}_{2}$ and $\mathrm{NO}_{\mathrm{x}}$. This equates to acidification impacts of approximately $0.8 \mathrm{~kg} \mathrm{SO}_{2}$-eq./ $\mathrm{kWh}$ for Dai et al. (2019) and $1.3 \mathrm{~kg} \mathrm{SO}$-eq. $/ \mathrm{kWh}$ for Kim et al. (2016). Other regional impacts, such as freshwater and marine eutrophication, co-vary with the acidification impacts. For eutrophication, the emissions are dependent on upstream material processing and energy use in production. These impacts reduce due to upscaling. Coupling production with renewable energy further lowers the impacts. Reductions in upstream emissions point to high material efficiency in the giga-factory as well as to the shift of cell geometry and cathode chemistry. Complete results for freshwater and marine eutrophication are reported in the SI.

\subsubsection{Human and ecological toxicity impacts}

Human (carcinogenic) toxicity impacts for the small-scale and giga-factory are shown in Fig. 5. The total amount of toxic emissions for the Small-3.7 model when coupled to the reference scenario and primary metals is approxi-

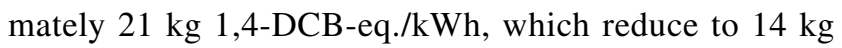

1,4-DCB-eq./kWh if the low-carbon scenario is considered. Emissions calculated with the Giga-3.7 model for the reference scenario and primary metals results in approximately $12 \mathrm{~kg}$ 1,4-DCB-eq./kWh, which reduces to $10 \mathrm{~kg}$ 1,4-DCB-eq./kWh when the low-carbon scenario is considered. However, when the Giga-3.7 model is coupled with recycled content input, the toxicity impacts increase to $15 \mathrm{~kg}$ 1,4-DCB-eq./kWh. Unlike the other environmental impacts analysed in the study, the toxicity impacts are lower when primary metals are used instead of recycled content in the giga-factory. This is due to higher steel use in the cylindrical cell produced in the giga-factory as compared to the pouch cell produced in the small-scale factory. Typically, low-alloyed steels are derived from steelmaking using either electric arc furnace (EAF) technology or a route via blast furnace (BF) ironmaking and blast oxygen furnace (BOF) steelmaking (Björkman and Samuelsson 2014). In the EAF, scrapped iron often accounts for all of the iron input, whereas the BF-BOF processes are ore-based, but often include a minor share of iron scrap used for cooling purposes (Ryman 2007). Steel production where scrap is the main input requires treatment processes to handle the slag produced in the EAF. Especially, if the EAF produces a variety of alloys, including stainless steel grades, or uses stainless steel scrap as input, these treatment processes cause chromium emissions, which are highly toxic. The primary only steel making processes modelled in this study excludes all EAF processing, as well as all iron scrap inputs to the ore-based route (BF-BOF). In such a setup, toxic emissions of chromium are largely avoided in primary low-alloyed
Fig. 5 Human carcinogenic toxicity impacts for the two factory models in the different carbon intensity scenarios. For the Giga-3.7 models, the effect of using primary metals reduces the toxicity impacts. Hence, the "added burden" becomes negative

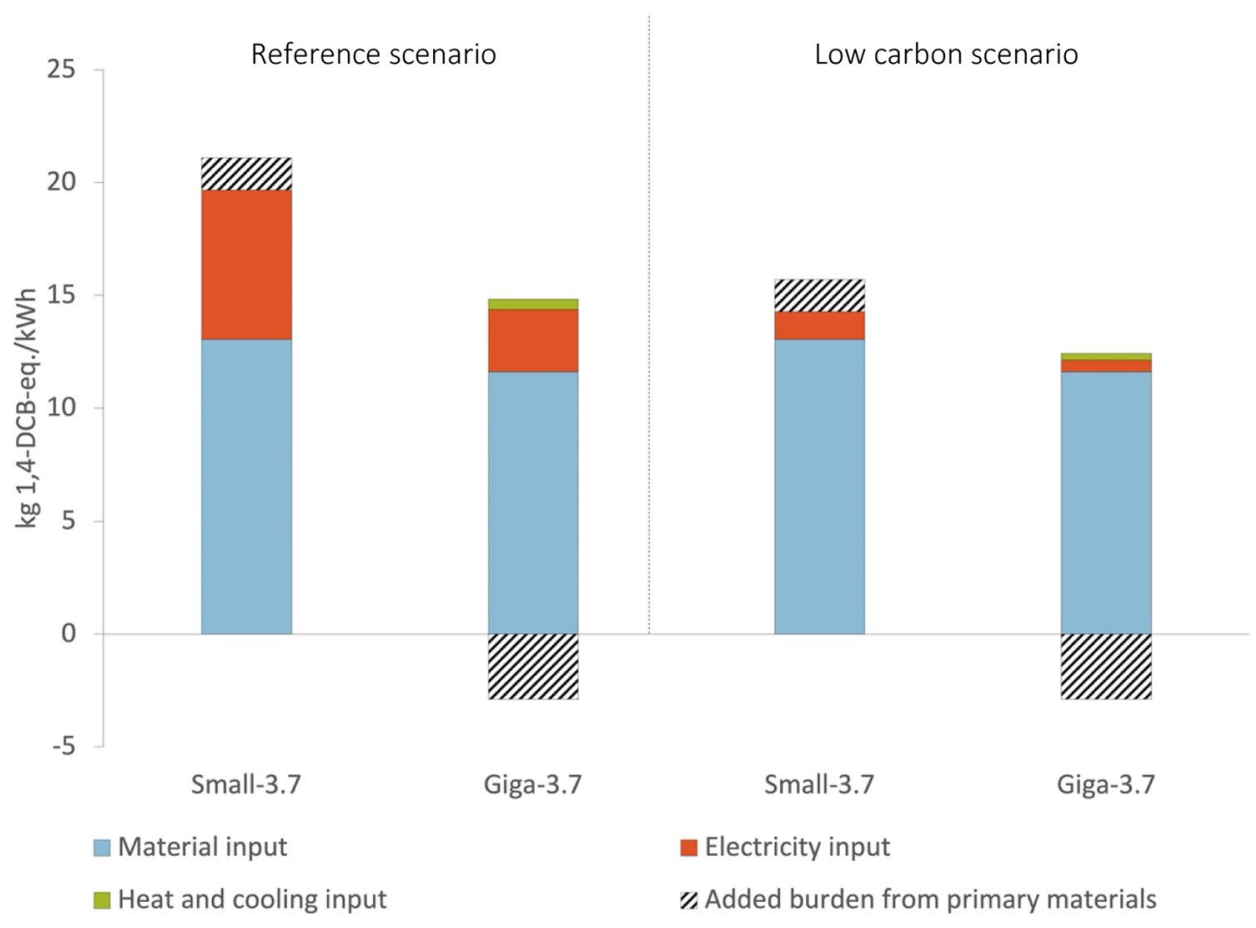


steel production, resulting in overall lower emissions as compared to producing recycled steels. Although this representation, where steel production is carried out without any scrap input is unlikely in the real world, this was a conscious methodological choice for maintaining consistency regarding modelling of primary material inputs with no share of recycled content. As a result, this study illustrates the effect of secondary steel production (using EAF technology) on toxic emissions linked to the scrap input that contain various grades and types of steel. Results for toxicity impacts from comparable large-scale production are not widely reported in literature. However, Sun et al. (2020) presented toxicity impacts of approximately $25 \mathrm{~kg}$ 1,4-DCB-eq./kWh for their NMC-6:2:2 cells produced in China, which is in the same order of magnitude as the results of this study.

Other toxicity impacts, including toxicity in freshwater, marine and terrestrial ecosystems, and human non-carcinogenic toxicity, all co-vary with the carcinogenic toxicity impacts for humans. For all toxicity impact categories, upscaling leads to an overall reduction in impacts. However, in contrast to nontoxicity-related impact categories, this reduction is mainly due to lower material inputs, thus indicating higher material efficiency in the giga-factory and highlighting the importance of different cell characteristics such as geometry and cathode chemistry. Specifically, freshwater, marine, and non-carcinogenic toxicity show a high burden for primary metal inputs in both factories, whereas the terrestrial toxicity is relatively unaffected by the choice of recycled versus primary metal inputs.

\subsubsection{Resource use impacts}

Figure 6 shows the results for two different mineral resource use assessment methods when cell production in the gigafactory is coupled to the low-carbon scenario and the use
Fig. 6 Resource use impacts in the Giga-3.7 model assessed using different mineral resource scarcity assessment methods

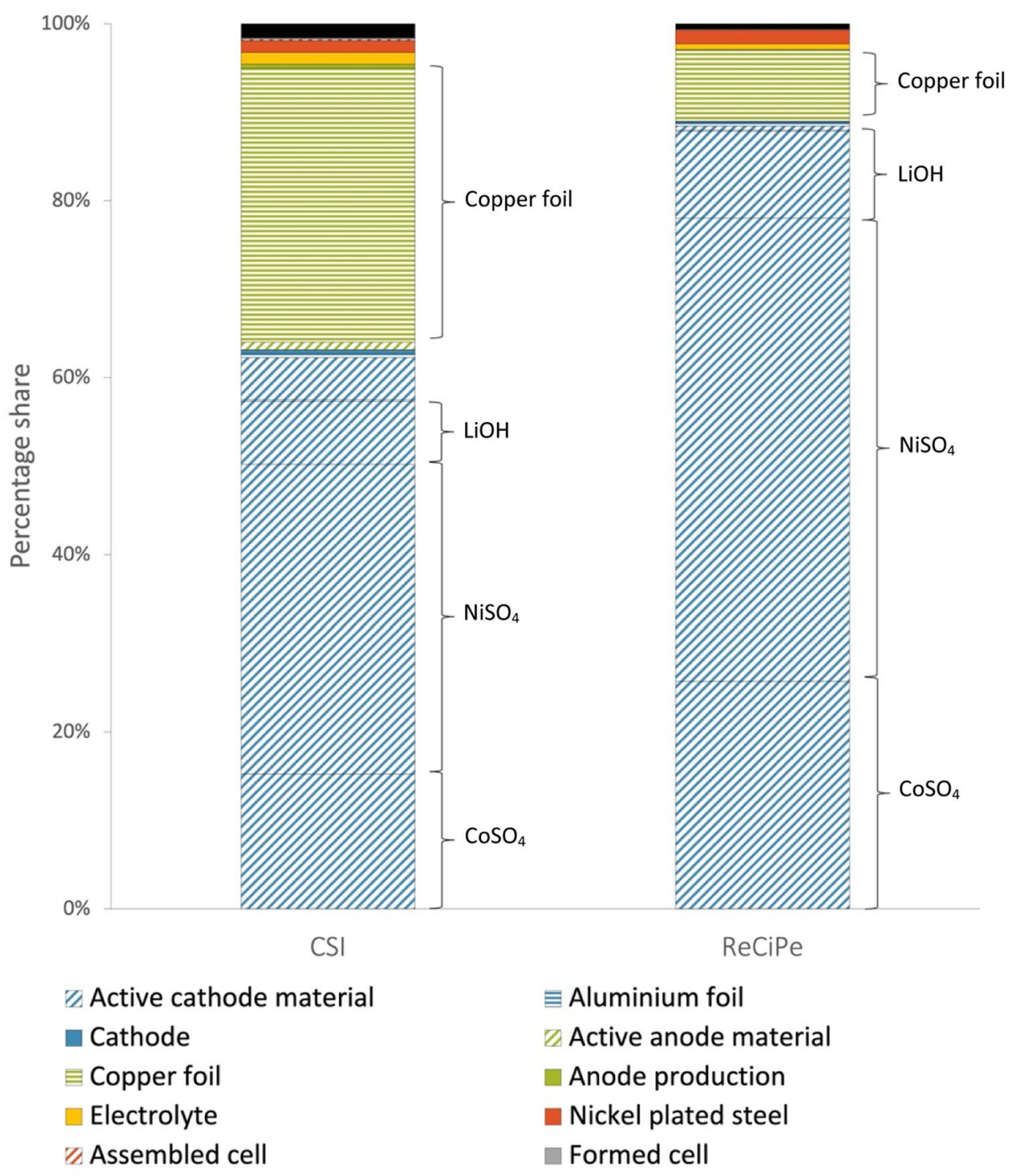

Factory const. \& oper. and WWT 
of primary metals only in the supply chain. The choice of energy mix showed to be of relatively low importance in this context, thus comparison with the reference scenario is not reported. Both methods used for analysis aim to address mineral resource scarcity, i.e., the surplus ore method of ReCiPe 2016 and the crustal scarcity indicator (CSI). However, conceptually, the two methods differ in their temporal coverages. The ReCiPe indicator characterizes minerals (and metals) based on ore grades and commodity prices, and results can vary over time for the same product system provided that the characterization factors are regularly updated. The CSI, on the other hand, considers only the crustal concentration of the metals in the Earth's crust, thus decoupling it from supply and demand dynamics pertaining to extraction rates and prices. Even so, the results show that the two methods converge in highlighting the contribution of active cathode materials to resource use impacts, especially the precursor materials nickel sulfate and cobalt sulfate as well as to a lesser extent lithium hydroxide. However, CSI also highlights the impacts from copper used in foils for current collectors that the ReCiPe method does not. This is an important long-term scarcity risk worth pointing out as copper is a highly relevant metal both in the context of batteries and in society in general due to its vast array of applications in the current industrial system (Kerr 2014).

Examining the production of nickel sulfate further reveals that its impacts from production are in fact due to co-production of cobalt during nickel mining. In attributional LCA modelling, co-production generally implies that the burdens of joint process step(s) are shared among all products outbound from that process, e.g., using mass based or economic allocation (Ekvall 2019). Particularly for mineral extraction, this adds complexity to the interpretation of metal use. For example, the use of nickel sulfate carries the burden for excavating ore containing both nickel and cobalt. In parallel, cobalt containing compounds deriving from co-production may then also carry the burden of some nickel. Copper use, e.g., in copper foils, is also linked to cobalt in a similar way as most cobalt globally is produced as a co-product of nickel and copper mining, and to a lesser extent mined with cobalt as a single main product (CDI 2016). The overall effect is that parts of the cell containing nickel and copper end up with high resource impacts because of co-produced cobalt, whereas cobalt containing parts have lower than expected resource impacts because of co-produced nickel and copper.

\section{Conclusion}

This study highlights the benefits of upscaling cell production of high nickel content cathode chemistries. When comparing production to a small-scale factory, the electricity demand per $\mathrm{kWh}$ cell storage capacity decreased by $58 \%$ in the giga-factory. The benefits of this reduction in energy demand are seen in multiple environmental impact indicators. For example, the global warming impacts decreased by $45 \%$ for the reference scenario and by another $55 \%$ if the energy is supplied in a low-carbon intensity scenario. As a result, the share of environmental burdens shifts upstream to material extraction and production. This is a key message for the mining and material production industry, and for policy makers, that further reductions in the climate impacts from LIB production are possible, only when the upstream LIB supply chain uses renewable energy sources.

Several other impact categories for which the energy use is an underlying factor co-varied with the global warming impacts. These include ground level ozone formation, particulate matter formation, stratospheric ozone depletion, and ionizing radiation. Regional impacts such as acidification and eutrophication follow a similar trend as the global warming impacts, but the burden of upstream material production carries a larger share than the factory operation also in the reference scenario. These impacts show a significant reduction due to upscaling, and using the low-carbon intensity electricity mix can further reduce the emissions. Toxicity impacts, including both human and ecological, predominantly occur in the upstream material production. Upscaling reduces toxicity impacts considerably, which points to higher material efficiency in large-scale production and a shift in favour of high-nickel content chemistries. This broad shift in several types of environmental burdens towards upstream stages calls for LIB supply chain actors to implement pollution control measures that can further reduce impacts, and for policy makers to outline clear directives to make this happen.

Furthermore, resource use impacts are highest for active cathode materials such as nickel sulfate and cobalt sulfate. This requires further investigation, as metals, including nickel and cobalt, are often co-produced from the same ore during mining. The CSI method used to assess the long-term scarcity also points to copper as a high-risk metal, which is a valuable insight given the wide application of copper in the modern industrial system. By replicating an older study on small-scale production, and then remodelling it with an updated background database, we highlight the importance of analyzing the quality and representativeness of the data source(s). This also exemplifies the effects of changes in the background system, when comparing impacts of similar product systems analyzed in studies conducted at different points in time. Finally, given the historical perspective taken in this study, an important message for LCA practitioners as well as agencies funding research for use in policy development is that maturing technologies must be regularly assessed for their impacts on the environment. 
Supplementary information The online version contains supplementary material available at https://doi.org/10.1007/s11367-021-01976-0.

Acknowledgements The authors would like to thank Rickard Arvidsson at Chalmers for feedback and insightful discussions on the manuscript, and the Swedish Electromobility Centre for funding the project. The authors would also like to thank Emma Nehrenheim, Camille Jourdain, and several additional anonymous experts at Northvolt $\mathrm{AB}$ for their time and effort in an ongoing dialogue around technical processes and operating procedures described in the permit applications and the energy report.

Author contribution $\mathrm{MC}$ and $\mathrm{AN}$ conceptualized the study together. $\mathrm{MC}$ conducted the data collection and formal analysis on all factory models. MC wrote the first manuscript draft along with visualization. AN supervised with review and supported data collection and analysis of the factory models, in particular the primary metal extraction. AN reviewed and edited the manuscript together with MC. LE provided feedback on the small-scale factory model, reviewed, and provided feedback on the manuscript.

Funding Open access funding provided by Chalmers University of Technology.

Data availability The research and analysis conducted in this study are based on primary data collection which is reported in the SI. Additionally, in Sect. S1, "Giga-factory model: general description and overview" of the SI, we provide complete details on data sources and design specifications of the LIB modelled in this study. This work was carried out in communication with our industry source to better interpret their technical data for representative purposes in the "Giga-3.7 LCA" model. Specific details on allocation of energy demand to different cell types produced in the cell factory are withheld due confidentiality reasons covered under a non-disclosure agreement. Still, complete inventory details are provided for modelling the cell type investigated in this study.

\section{Declarations}

Conflict of interest The authors declare no competing interests.

Open Access This article is licensed under a Creative Commons Attribution 4.0 International License, which permits use, sharing, adaptation, distribution and reproduction in any medium or format, as long as you give appropriate credit to the original author(s) and the source, provide a link to the Creative Commons licence, and indicate if changes were made. The images or other third party material in this article are included in the article's Creative Commons licence, unless indicated otherwise in a credit line to the material. If material is not included in the article's Creative Commons licence and your intended use is not permitted by statutory regulation or exceeds the permitted use, you will need to obtain permission directly from the copyright holder. To view a copy of this licence, visit http://creativecommons.org/licenses/by/4.0/.

\section{References}

Ahmed S, Nelson PA, Gallagher KG, Dees DW (2016) Energy impact of cathode drying and solvent recovery during lithium-ion battery manufacturing. J Power Sources 322:169-178

Aichberger C, Jungmeier G (2020) Environmental life cycle impacts of automotive batteries based on a literature review. Energies 13(23)
Arora P, White R, Doyle M (1998) Capacity fade mechanisms and side reactions in lithium-ion batteries. J Electrochem Soc 145(10):3647

Arvidsson R, Chordia M, Wickerts S, Nordelöf A (2020a) Implementation of the crustal scarcity indicator into life cycle assessment software. Chalmers University of Technology, Gothenburg

Arvidsson R, Söderman ML, Sandén BA, Nordelöf A, André H, Tillman A-M (2020b) A crustal scarcity indicator for long-term global elemental resource assessment in LCA. The Int J LCA

Ausenco (2020) Association for the Advancement of Cost Engineering (AACE) Class 3 Feasibility Study — First Cobalt Refinery Project, Ontario, Canada. Vancouver, Canada: Ausenco Engineering Canada

Ball S, Clark J, Cookson J (2020) Battery materials technology trends and market drivers for automotive applications. Johnson Matthey Technology Review

Baumann H, Tillman A-M (2004) The Hitch Hiker's guide to LCA. Sweden

Benchmark Mineral Intelligence (2020) We are over Elon Musk's 100 Gigafactory target for sustainable energy: do we need a terafactory? Benchmark Mineral Intelligence

Björkman B, Samuelsson C (2014) Chapter 6 - Recycling of steel. In Handbook of recycling, edited by E. Worrell and M. A. Reuter. Boston: Elsevier

Blomgren GE (2016) The development and future of lithium ion batteries. J Electrochem Soc 164(1):A5019-A5025

CDI (2016) The Environmental Performance of Refined Cobalt. United Kingdom: Cobalt Development Institute

Crabtree G (2019) The coming electric vehicle transformation. Science 366(6464):422

Crenna E, Gauch M, Widmer R, Wäger P, Hischier R (2021) Towards more flexibility and transparency in life cycle inventories for Lithium-ion batteries. Resour Conserv Recycl 170:105619

Crundwell F, Moats M, Ramachandran V, Robinson T, Davenport WG (2011) Extractive metallurgy of nickel, cobalt and platinum group metals: Elsevier

Dai Q, Winjobi O (2019) Updates for battery recycling and materials in GREET 2019. Argonne National Laboratory

Dai Q, Kelly CJ, Elgowainy A (2018a) Cobalt life cycle analysis update for the GREET Model. Argonne National Laboratory

Dai Q, Dunn J, Kelly CJ, Elgowainy A (2017) Update of life cycle analysis of lithium-ion batteries in the GREET model. Argonne National Laboratory

Dai Q, Kelly J, Dunn J, Benavides P (2018b) Update of bill-of-materials and cathode materials production for lithium-ion batteries in the GREET Model

Dai Q, Kelly CJ, Gaines L, Wang M (2019) Life cycle analysis of lithium-ion batteries for automotive applications. Batteries 5(2)

Deng Y, Ma L, Li T, Li J, Yuan C (2018) Life cycle assessment of silicon-nanotube-based lithium ion battery for electric vehicles. ACS Sustain Chem Eng 7(1):599-610

Ding Y, Cano ZP, Yu A, Lu J, Chen Z (2019) Automotive Li-ion batteries: current status and future perspectives. Electrochem Energy Rev 2(1):1-28

Dunn J, Gaines L, Kelly J, James C, Gallagher K (2015a) The significance of Li-ion batteries in electric vehicle life-cycle energy and emissions and recycling's role in its reduction. Energy Environ Sci 8(1):158-168

Dunn JB, James C, Gaines L, Gallagher K, Dai Q, Kelly JC (2015b) Material and energy flows in the production of cathode and anode materials for lithium ion batteries. Argonne National Lab.(ANL), Argonne, IL (United States)

Egede P (2017) Environmental assessment of lightweight electric vehicles: Springer

Ekvall T (2019) Attributional and Consequential Life Cycle Assessment. Gothenburg: Intech open

Ellingsen L, Majeau-Bettez G, Stromman AH (2015) Comment on The significance of Lâ ion batteries in electric vehicle lifÖ cycle 
energy and emissions and recycling's role in its reductioé in Energy \& Environmental Science. J Ind Ecol 19:518-519

Ellingsen LA-W, Hung CR, Strømman AH (2017) Identifying key assumptions and differences in life cycle assessment studies of lithium-ion traction batteries with focus on greenhouse gas emissions. Transport Res D-Tr E 55:82-90

Ellingsen LAW, Majeau-Bettez G, Singh B, Srivastava AK, Valøen LO, Strømman AH (2014) Life cycle assessment of a lithiumion battery vehicle pack. J Ind Ecol 18(1):113-124

European Copper Institute (2012) The environmental profile of copper products. European Copper Institute, Brussels

Fthenakis V, Wang W, Kim HC (2009) Life cycle inventory analysis of the production of metals used in photovoltaics. Renew Sust Energ Rev 13(3):493-517

Gediga J, Sandilands J, Roomanay N, Boonzaier S (2015) Life cycle assessment of Nickel products. Leinfelden-Echterdingen: The Nickel Institute

Gourley SWD, Or T, Chen Z (2020) Breaking free from cobalt reliance in lithium-ion batteries. iScience 23(9):101505.

Greene DL, Liu C, Park S (2013) Transition from Petro-Mobility to Electro-Mobility. In Transition to Renewable Energy Systems

Holland SP, Mansur ET, Muller NZ, Yates AJ (2016) Are there environmental benefits from driving electric vehicles? The importance of local factors. Am Econ Rev 106(12):3700-3729

Huijbregts MA, Steinmann ZJ, Elshout PM, Stam G, Verones F, Vieira M, Zijp M, Hollander A, van Zelm R (2017) ReCiPe2016: A harmonised life cycle impact assessment method at midpoint and endpoint level. The Int J LCA 22(2):138-147

ICCT (2020) Update on the global transition to electric vehicles through 2019: The International Council for Clean Transportation

Kelly JC, Dai Q, Wang M (2019) Globally regional life cycle analysis of automotive lithium-ion nickel manganese cobalt batteries. Mitig Adapt Strat Gl:1-26.

Kerr RA (2014) The Coming Copper Peak. Science 343(6172): 722

Kim HC, Wallington TJ, Arsenault R, Bae C, Ahn S, Lee J (2016) Cradle-to-gate emissions from a commercial electric vehicle li-ion battery: A comparative analysis. Environ Sci Technol 50(14):7715-7722

Lejestrand A (2020) Fjärrkylestatistik 2019. https://www.energiforetagen. se/statistik/fjarrkylestatistik/. Accessed 5 May 2021

Li W, Erickson EM, Manthiram A (2020) High-nickel layered oxide cathodes for lithium-based automotive batteries. Nat Energy 5(1):26-34

Ludwig B, Zheng Z, Shou W, Wang Y, Pan H (2016) Solvent-free manufacturing of electrodes for lithium-ion batteries. Sci Rep 6(1):23150

Lutsey N, Grant M, Wappelhorst S, Zhou H (2018) Power play: how governments are spurring the electric vehicle industry. International Council for Clean Transportation, Washington

Majeau-Bettez G, Hawkins TR, Strømman AH (2011) Life cycle environmental assessment of lithium-ion and nickel metal hydride batteries for plug-in hybrid and battery electric vehicles. Environ Sci Technol 45(10):4548-4554

Manthiram A (2017) An outlook on lithium ion battery technology. ACS Cent Sci 3(10):1063-1069

Memary R, Giurco D, Mudd G, Mason L (2012) Life cycle assessment: a time-series analysis of copper. J Clean Prod 33:97-108

Moats MS, Davenport WG (2014) Chapter 2.2 - Nickel and cobalt production. In Treatise on process metallurgy, edited by $\mathrm{S}$. Seetharaman. Boston: Elsevier

Nelson PA, Ahmed S, Gallagher KG, Dees DW (2019) Modeling the performance and cost of lithium-ion batteries for electric-drive vehicles. Argonne National Lab.(ANL), Argonne, IL (United States)

Nordelöf A, Messagie M, Tillman A-M, Söderman ML, Van Mierlo J (2014) Environmental impacts of hybrid, plug-in hybrid, and battery electric vehicles-what can we learn from life cycle assessment? The Int J LCA 19(11):1866-1890

Northvolt (2017) Northvolt Ett - Anläggning för storskalig produktion av litiumjonbatterier. Bergsbyns industriområde, Skellefteå: Northvolt AB

Northvolt (2018) Teknisk beskrivning Northvolt Ett - Utökad anläggning för storskalig produktion av litiumjonbatterier. Bergsbyns industriområde, Skellefteå: Northvolt $\mathrm{AB}$

Northvolt (2019) Teknisk beskrivning Northvolt Ett - Utbyggnad av anläggning för storskalig tillverkning av batterier och ny anläggning för återvinning av litiumjonbatterier, samt uttag av vatten från Skellefteälv. Bergsbyns industriområde, Skellefteå

Northvolt (2020) Energieffektivisering enligt utredningsvillkor U4. Northvolt AB

Olivetti EA, Ceder G, Gaustad GG, Fu X (2017) Lithium-ion battery supply chain considerations: Analysis of potential bottlenecks in critical metals. Joule 1(2):229-243

Onat NC, Kucukvar M, Tatari O (2015) Conventional, hybrid, plugin hybrid or electric vehicles? State-based comparative carbon and energy footprint analysis in the United States. Appl Energy 150:36-49

Peters JF, Weil M (2018) Providing a common base for life cycle assessments of Li-Ion batteries. J Clean Prod 171:704-713

Peters JF, Baumann M, Zimmermann B, Braun J, Weil M (2017) The environmental impact of Li-Ion batteries and the role of key parameters-a review. Renew Sust Energ Rev 67:491-506

Philippot M, Alvarez G, Ayerbe E, Van Mierlo J, Messagie M (2019) Eco-efficiency of a lithium-ion battery for electric vehicles: Influence of manufacturing country and commodity prices on GHG emissions and costs. Batteries 5(1):23

Pinegar H, Smith YR (2019) Recycling of end-of-life lithium ion batteries, Part I: Commercial processes. J Sust Metall 5(3):402-416

Quinn JB, Waldmann T, Richter K, Kasper M, Wohlfahrt-Mehrens M (2018) Energy density of cylindrical Li-ion cells: A comparison of commercial 18650 to the 21700 cells. J Electrochem Soc 165(14):A3284-A3291

Raugei M, Winfield P (2019) Prospective LCA of the production and EoL recycling of a novel type of Li-ion battery for electric vehicles. J Clean Prod 213:926-932

Ryman C (2007) On the use of process integration methods: evaluation of energy and $\mathrm{CO} 2$ emission strategies in blast furnace ironmaking and oxygen steelmakingthesis, Luleå tekniska universitet.

Sharma SS, Manthiram A (2020) Towards more environmentally and socially responsible batteries. Energy Environ Sci 13(11):4087-4097

Smekens J, Gopalakrishnan R, Steen N, Omar N, Hegazy O, Hubin A, Van Mierlo J (2016) Influence of electrode density on the performance of Li-ion batteries: Experimental and simulation results. Energies 9(2): 104

Steubing B, Wernet G, Reinhard J, Bauer C, Moreno-Ruiz E (2016) The ecoinvent database version 3 (part II): analyzing LCA results and comparison to version 2. The Int J LCA 21(9):1269-1281

Strauch Y (2020) Beyond the low-carbon niche: global tipping points in the rise of wind, solar, and electric vehicles to regime scale systems. Energy Res Soc Sci 62:101364

Sun X, Luo X, Zhang Z, Meng F, Yang J (2020) Life cycle assessment of lithium nickel cobalt manganese oxide (NCM) batteries for electric passenger vehicles. J Clean Prod 273:123006.

Tsiropoulos I, Tarvydas D, Lebedeva N (2018) Li-ion batteries for mobility and stationary storage applications - scenarios for costs and market growth. ISBN 978-92-79-97254-6. Luxembourg: European Commission

USGS (2020) Mineral commodity summaries 2020. Reston, VA

Wang F, Deng Y, Yuan C (2019) Comparative life cycle assessment of simicon nanowire and silicon nanotube based lithium ion batteries 
for electric vehicles. Paper presented at 26th CIRP Life Cycle Engineering (LCE) Conference

Wang M, Elgowainy A, Benavides PT, Burnham A, Cai H, Dai Q, Hawkins TR, Kelly JC, Kwon H, Lee D-Y (2018) Summary of expansions and updates in GREET® 2018. Argonne National Lab. (ANL), Argonne, IL (United States)

Weidema B, Bauer C, Hischier R, Mutel C, Nemecek T, Reinhard J, Vadenbo C, Wernet G (2013) The ecoinvent database: overview and methodology, data quality guideline for the ecoinvent database version 3. Zürich: Ecoinvent Center Retrieved(Der folgende Link führt zur zuvor genannten Veröffentlichung: www ecoinvent org)

Wentker M, Greenwood M, Leker J (2019) A bottom-up approach to lithium-ion battery cost modeling with a focus on cathode active materials. Energies 12(3)

Wernet G, Bauer C, Steubing B, Reinhard J, Moreno-Ruiz E, Weidema B (2016) The ecoinvent database version 3 (part I): overview and methodology. The Int J LCA 21(9):1218-1230
Wood DL, Li J, Daniel C (2015) Prospects for reducing the processing cost of lithium ion batteries. J Power Sources 275:234-242

Wood DL, Quass JD, Li J, Ahmed S, Ventola D, Daniel C (2018) Technical and economic analysis of solvent-based lithiumion electrode drying with water and NMP. Drying Technol 36(2):234-244

Yuan C, Deng Y, Li T, Yang F (2017) Manufacturing energy analysis of lithium ion battery pack for electric vehicles. CIRP Ann 66(1):53-56

Zackrisson M, Avellán L, Orlenius J (2010) Life cycle assessment of lithium-ion batteries for plug-in hybrid electric vehicles - critical issues. J Clean Prod 18(15):1519-1529

Publisher's Note Springer Nature remains neutral with regard to jurisdictional claims in published maps and institutional affiliations. 